J. Dairy Sci. 95:3479-3479

http://dx.doi.org/10.3168/jds.2012-95-6-3479

(C) American Dairy Science Association ${ }^{\circledR}, 2012$.

\title{
Erratum to "Use of a corn milling product in diets for dairy cows to alleviate milk fat depression” (J. Dairy Sci. 95:2081-2090)
}

\section{W. P. Weiss}

In the section on milk fatty acids (page 2086) and in Table 7 (page 2088), a fatty acid was identified as cis10,trans-12 CLA. The correct designation is trans-10, cis-12 CLA.

The author regrets the error.

\section{REFERENCES}

Weiss, W. P. 2012. Use of a corn milling product in diets for dairy cows to alleviate milk fat depression. J. Dairy Sci. 95(4):2081-2090. 